The Madwoman in the Attic 
This page intentionally left blank 
A VERITAS PAPERBACK

\section{The Madwoman in the Attic}

THE WOMAN WRITER AND

THE NINETEENTH-CENTURY

LITERARY IMAGINATION

SANDRA M. GILBERT

and SUSAN GUBAR

WITH AN INTRODUGTION

BY LISA APPIGNANESI

Yale UNIVERSITY PRESS

NEW HAVEN AND LONDON 
Veritas paperback edition, 2020

Copyright (C) 1979 by Yale University.

Copyright (C) 1984 by Sandra M. Gilbert and Susan Gubar.

Introduction to the Veritas paperback edition copyright (C) 2020 by Lisa Appignanesi.

All rights reserved.

This book may not be reproduced, in whole or in part, in any form (beyond that copying permitted by Sections 107 and 108 of the U.S. Copyright Law and except by reviewers for the public press), without written permission from the publishers.

The Madwoman in the Attic was originally published in 1979 by Yale University Press. The second edition was published in 2000 by Yale University Press. The Veritas paperback is based on the second edition.

For information about this and other Yale University Press publications, please contact: U.S. office sales.press@yale.eduＵ.K. office sales@yaleup.co.uk

Printed in the United States of America.

The Library of Congress has catalogued the second edition as follows:

Gilbert, Sandra M.

The madwoman in the attic: the woman writer and the nineteenth-century literary imagination / Sandra M. Gilbert and Susan Gubar.-2nd. ed. p.cm.

Includes bibliographical references and index.

ISBN 978-0-300-08458-0

1. English literature - Women authors - History and criticism. 2. English literature19 th century - History and criticism. 3. Women in literature. 4. Women authorsPsychology. 5. English literature-Psychological aspects. I. Gubar, Susan, 1944- II. Title. PR115.G5 2000

820.9'9287'09034 dc21 99-086038

Veritas Paperback Edition ISBN: 978-0-300-24672-8

A catalogue record for this book is available from the British Library.

Credits appear on page 721 .

$\begin{array}{llllllllll}10 & 9 & 8 & 7 & 6 & 5 & 4 & 3 & 2 & 1\end{array}$ 
This book is as much for Edward, Elliot, and Roger, as it is for Kathy, Molly, Sandra, Simone, Susan, and Susanna. 
This page intentionally left blank 
The strife of thought, accusing and excusing, began afresh, and gathered fierceness. The soul of Lilith lay naked to the torture of pure interpenetrating inward light. She began to moan, and sigh deep sighs, then murmur as if holding colloquy with a dividual self: her queendom was no longer whole; it was divided against itself. ... At length she began what seemed a tale about herself, in a language so strange, and in forms so shadowy, that I could but here and there understand a little.

—George MacDonald, Lilith

It was not at first clear to me exactly what I was, except that I was someone who was being made to do certain things by someone else who was really the same person as myself-I have always called her Lilith. And yet the acts were mine, not Lilith's.

-Laura Riding, "Eve's Side of It" 
This page intentionally left blank 